\title{
Place-Based Readings Toward Disrupting Colonized Literacies: A Métissage
}

Adrian M. Downey, Rachael Bell, Katelyn Copage, and Pam Whitty

University of New Brunswick

\section{Authors' Note}

All communications regarding this manuscript can be directed to Adrian M. Downey at Adowney3@unb.ca

\begin{abstract}
Working from the premise that learning to live well in our places is quickly becoming a necessity of human survival, in this article we weave together divergent experiences of our shared place, the Wabanaki Confederacy or Eastern Canada, and literatures and literacies of that place. This article is methodologically framed using the concept of "métissage" as it has been taken up in Canadian curriculum studies as a form of intertextual life writing. Through our métissage, we are ultimately concerned with theorizing the idea of reading place - making sense of the ways in which settler colonialism has historically made, and continues to make, itself felt on Land. The idea of reading place, however, also demands that we actively engage in disrupting the normativity of settler colonial presence on Land-particularly as manifest through literature and literacy. Toward speaking back to the normativity of this settler colonial presence, the authors draw on divergent pedagogical and literary practices toward ensuring indigenous futurities.
\end{abstract}

Keywords: settler colonialism; literacies of the land; literacy
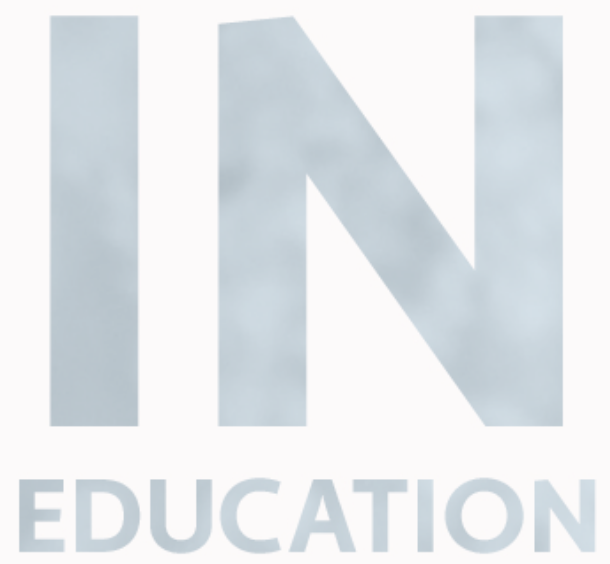


\section{Place-Based Readings Toward Disrupting Colonized Literacies: A Métissage}

\section{The Imperatives of Reading Place}

Knowing how to live well in our places has become more than an ethical imperative. It has become a necessity of human survival. Nearly 25 years ago, David Orr (1994) famously and frankly stated, "The plain fact is that the planet does not need more successful people. But it does desperately need more peacemakers, healers, restorers, storytellers, and lovers of every kind. It needs people who live well in their places [emphasis added]" (p. 12). Today Orr's words resonate with threatening clarity: European heat waves, British Columbian forest fires, Californian droughts, and the flooding of waterways in Eastern Canada permeate news headlines. Hidden behind each climatic event is a collective wonderment of how the human race arrived here and how, if possible, we will make things different in the future.

In this article, we are concerned with understanding how to live well in place and how to help others do the same, learning from one another in the process. In particular, we are concerned with understanding the literary legacies of colonialism as manifest on Land. ${ }^{1}$ How can we, as educators in a variety of capacities, work toward understanding those legacies, challenging and disrupting their assumed normativity, and reclaiming/reasserting longstanding, traditional indigenous $^{2}$ understandings of place? As two Indigenous educator/scholars and two nonIndigenous educator/scholars, we approach this topic, embedded with literary legacies of colonialisms deeply ingrained in our beings, bodies, minds, hearts, and stories, by sharing our personal stories of learning to "read place" through métissage.

We take up métissage as articulated by Canadian and Indigenous curriculum scholars such as Erika Hasebe-Ludt (2010), Cynthia Chambers et al. (2008), and Dwayne Donald (2012). From this perspective, métissage is a literary form and method of life writing which "braids" together lived experiences through enacting "genuine exchange, sustained engagement, and the tracing of 'mixed and multiple identities' in the 'messy threads of relatedness and belonging"' (Hasebe-Ludt \& Jordan, 2010, p. 3). We carry forward métissage as one way to articulate a complex and nuanced reading of our shared place-the unceded and unpurchased territory of the Wabanaki ${ }^{3}$ Confederacy.

The Wabanaki Confederacy is the term given to the international (Simpson, 2017a) union of the Mi'kmaq, Wolastoqiyik, Passamaquoddy, Abenaki, and Penobscot nations - those nations whose traditional territory comprises most of Atlantic Canada and parts of Quebec, Maine, Vermont, and Connecticut. The intertwined history of peace and friendship among these nations extends back before contact (Paul, 2006, 2017). In Atlantic Canada, the Wabanaki Nations signed Peace and Friendship Treaties with the British Crown between 1725 and 1763, which solidified Wabanaki sovereignty within Wabanaki territory (Battiste, 2016a). Each of these treaties were ultimately broken by the British (Paul, 2006), and the expansive territory of the Wabanaki Nations was systematically carved up for the (exploitative and extractive) use of settlers (Bear Nicholas, 2011; Paul, 2006). Despite the systematic dispossession and attempted erasure experienced by the nations of the Wabanaki Confederacy, today the Wabanaki Confederacy still stands, particularly as a marker of the cultural and political friendship between nations (See George, 2019a; Mitchell, 2018; Kress, Perley, Perley, Plaice, \& Sabattis-Atwin, 2019).

In this paper, each of us will share our personal experience of learning and helping others to read, speak back to, and/or live in tension with the colonial realities, histories, and literatures of 
the Land - or what we refer to as "reading place." We open our métissage with background knowledge about our conversations and the theories that guide our thinking. From there, our conversations are presented in three strands: where our hearts lie, reading rivers, and future making. The first strand, where our hearts lie, articulates our situatedness in relationship to Land, each other, and the reader. In the second strand, reading rivers, we share personal stories of learning to read our place with/through Land using the binding metaphor of the river. The third strand, future making, shifts the conversation from learning into becoming as we envision ways of bringing our understandings into action. We conclude the paper by braiding these strands together in the section labeled "Tying Off"; however, we do so loosely with the intent of leaving all that we have said open to (re)interpretation. In conceptualizing the structure of our métissage, it may be useful to think of sweetgrass, in the braiding of which many individual blades are brought together to form a single strand, three of which are then braided together. Sweetgrass is fragile when there are only a few blades, but when thickly braided together it is difficult to break. Likewise, we think of the sharing that goes into métissage as a form of collectively strengthening our understanding of what it means to read place and thereby live well within it.

\section{Opening}

As four people/voices, we have been meeting over the last year, carrying on conversations in person, in google docs, and perhaps most powerfully in our own heads and hearts. Collectively, we have held relational space - space marked by deep reciprocity, mutual respect, care, and generosity - for each other to think/feel/share understandings of self, place, and the relationships between them. As individuals, we have paid attention to how Land speaks to each of us so that we might bring these encounters together and make meaning of our sensibilities, wonderments, and questions as we continue our conversations about/with Land and what we are hearing, noticing, and living.

Land and literature are intimately connected. Beyond the fact that all literature is placedmeaning it occurs within a particular, inhabited spatial reality, whether actual or fictitiousnumerous Indigenous scholars have noted the intimate understanding of Land embedded in the traditional stories of many Indigenous communities (e.g., Simpson, 2017a; Styres, 2019; Tuck \& McKenzie, 2015). Sandra Styres (2019), an academic of Kanien'kehá:ka (Mohawk), English, and French ancestry, has articulated the capacity of Indigenous peoples to read the stories and knowledges embedded in understandings of Land as "literacies of the land" (p. 24). Just as settler colonialism pushed toward the disappearance of Indigenous peoples from the land-dispossession (Simpson, 2017a) and erasure (Tuck \& McKenzie, 2015)—so too did settler colonial literary traditions make ghosts of Indigenous people and the literacies of the lands upon which they dwell.

As educators and scholars, we are influenced by Styres' (2019) approach to literacies as:

Rooted in and informed by understandings of the Land and self-in-relationship that opens opportunities for decolonizing frameworks and praxis that critically trouble and disrupt colonial myths and stereotypical representations embedded in normalizing, hegemonic discourses and relations of power and privilege. (pp. 24-25)

Power is embedded in limited definitions of literacy and the ways in which those limited definitions have been used to marginalize particular skills and bodies of knowledge over time (Battiste, 1984; Kuby, Spector, \& Johnson Thiel, 2019; Zaidi \& Rowsell, 2017). The history is one of literary violence in our territory, and that Mi'kmaw discursive systems were ignored and 
devalued by colonial settlers and eventually replaced with colonially created hieroglyphic systems meant to facilitate the rote memorization of prayer and the conversion of the Mi'kmaw people (Battiste, 1984, 2013, 2016b). Further, colonial settlers were unable to see-hear the pre-existing indigenous knowledges and literacies, such as the Wolustaqey mnemonic knowledge of the landscape (Bryant, 2017).

Place names have significance, particularly in light of our solidarity and internation relationship with the Wolastoqiyik, the people of the beautiful and bountiful river - the Wolastoq river, today known as the St. John River. The relationship between the Wolastoqiyik and the river from which their name is derived is long and storied: "For thousands of years, Wolastoq provided for all the needs of families and communities along its shores including food, medicine and transportation" (Perley \& Beaton, 2019, n.p.). Today, there is an ongoing effort to reclaim and reassert the original name of the river, and the Wolastoq Grand Council (as cited in Glynn, 2017) has stated that, "Wolastoq is our identity... scientific studies have now confirmed what our people have always known: water has memory. Once we address the river as Wolastoq, this river will remember its original name" (n.p.). Pollution in the river has been a huge problem stemming from a history of extractive industries in the province (DeMont, 1992; Perley \& Beaton, 2019), but the river and the land that surrounds it remain a source of cultural knowledge and spiritual significance for the Wolastoqiyik.

The mapping of the name St. John River over top of the pre-existing "Wolastoq" is an example of the erasure of indigenous literary legacies. Many other examples are clear in the canon of Atlantic Canadian literature and literary scholarship. Settler-scholar Rachel Bryant (2017) argues, for example, that when John Gyles (1736) wrote his autobiographical account (published in 1736) of living with the Wolastoqiyik as a "captive" for nine years, he depicted a wild, primitive people, yet hinted at the potential for the brilliant indigenous knowledges embedded in Wolustaqey worldview and particularly the ways the stories of the Wolastoqiyik understood "the land itself as a narrative" (p. 54). Gyles was changed by his experience of living with the Wolastoqiyik; he was able to see what settler society had collectively unseen about Indigenous peoples - that Indigenous peoples were/are brilliant. Bryant theorizes that the literary genre of the captive narrative and broader social conventions of the time prevented Gyles from articulating the brilliance of indigenous knowledge he encountered. This is but one example of the many ways in which indigenous knowledges and literacies were unseen and erased through settler literary traditions. Indeed, for every story of settlement, there is at least one story of erasure that complicates it.

When we push back against that which has been erased or made absent from our understanding, there is an embodied dissonance that goes along with the (re)new(ed) presence. In this paper, we aim to displace these erasures and absences through re-encountering conversations and co-creating métissage. We, thus, examine divergent literacies and literatures through which we attempt to more deeply understand our sense of place and, in so doing, push back against the erasure of indigenous literacies and literatures within our territory. The understandings toward which we are moving are situated within what Bryant (2017) theorizes as cartographic dissonance, "the ability to hold two or more 'competing' conceptualizations of a single geographic space in one's imagination" (p. 180).

In the context of Bryant's work, cartographic dissonance occurs when the containment, concealment, and assimilation of indigenous literacies and literatures, which have existed for approximately 13,500 years in this territory, are recovered and begin to destabilize colonial 
literacies/literatures that more recently have concealed, written over, or assimilated indigenous literacies/literary genres. We are interested in making sense of entwined colonial histories/literacies and ongoing endemic colonial systems of oppression (Brayboy, 2005) at work within the traditional territories of the Wabanaki Confederacy. Toward this end, we bring our voices together with indigenous resurgent poetics, stories, songs, images, dramatics, and Land, elucidating ways of being differently literate in the present and future. These diverse literary genres - based in both indigenous and settler traditions-create and complicate cartographic dissonance. Ultimately, through this métissage we seek to engage cartographic dissonance through our diverse personal experience.

\section{Strand One: Where Our Hearts Lie}

Writing from a Cree perspective, Michael Anthony Hart (2002) acknowledges the importance of relationship and the impossibility of constructing relationship through written text: "While I cannot truly share myself with you in ways that you would come to know me as a human being, I offer these few words as a step toward understanding where my heart lies" (p. 14). In this first strand, we follow the lead of Hart and many other Indigenous scholars in beginning with who we are so that you may start the journey of building a relationship with us-so you will know where our hearts lie.

\section{Adrian}

G'wey. Niin teluisi Adrian Downey, aqq telayawi Jipuktuk aqq nt ni'gmaw telayawultijik ktaqamkuk. Now I live in Fredericton where I am a PhD candidate, but I haven't figured out how to say that in Mi'kmaw yet.

My grandfather's name was Nolan Bennett. He was a Mi'kmaw fisherman who lived most of his life in St. George's, Newfoundland. My grandfather was born and passed into the spirit world as Mi'kmaq, but not as an Indian. He was one of many unrecognized Indigenous people of Newfoundland. He was also a keeper of the language, and my aunt shared with me recently that my grandfather would sing to her in Mi'kmaw language to help her get to sleep when she was young.

Today, my maternal family are all members of the Qalipu Mi'kmaw First Nation. My journey in the last ten years has been one of trying to understand what that means, what my responsibilities are, and how to be a good ancestor for the next seven generations-borrowing Daniel Heath Justice's (2018) terminology. Recently, I have been carrying my grandfather's legacy forward with music and poetry, and by learning Mi'kmaw language. In each new word I learn, I start to see the world in slightly different terms, and the way I read place changes. Here, I hope to share some of those insights.

\section{Pam}

As a White-settler Canadian, female, anglophone professor, I benefit in multiple ways from living and working on Wolustaqey lands, upon which the province of New Brunswick, Canada was mapped in 1784 (Paul, 2006). My relatives and I have lived on the traditional lands of the Wabanaki Nations since the early 1800 s when as Irish immigrants, Whitty families took leave of County Wexford and settled in an area near what was later named the Inkerman parish in northern New Brunswick, eventually settling on the Miramichi River. They came after the Loyalists and prior to the Irish famine for work generated as a consequence of large stands of timber taken for 
shipbuilding, mast making, and lumbering - eventually replaced with pulp mills, now almost nonexistent.

I am visiting the Inkerman graveyard, standing at John Whitty's headstone. I am amazed at how easily I found it. After catching my breath and tracing John Whitty's name, birth, emigration and death details with my fingertips, I look up from his name/my name and across the Mi'kmaw landscape and its energizing greenness. This land evokes the Wexford homelands of my settler ancestors - the place from which my relatives emigrated. And in the midst of this greenness and late spring warmth, I wonder: were my settler ancestors taken aback by the winter whiteness and the depths of cold just six months away? How did their encounters with the original and longstanding habitants of this land contribute to their/our/my survival? Wolustoqik scholar and Elder Dr. David Perley (n.d.) articulates the contributions First Nations people made to settlers including knowledge of the land, survival skills, and medicines; Wabanaki architecture and winter shelters; democratic government; labour for various economic activities; and land for White settlement. My ancestors and I benefit/ted greatly from ways of knowing and being that have existed and emerged from/with this land and the Wabanaki peoples for over 13,000 years prior to our arrival (Mitchell, 2018; O’Donnell, n.d.; Paul, 2006; Perley, n.d.; Pictou, 2017; see also Cajete, 1994, 2000).

\section{Rachael}

My name is Rachael Bell, and I am a settler who lives, works, and teaches in Miramichi, New Brunswick. My city draws its name from the long and mighty river that runs through it, and the river's first name comes from the Mi'kmaw language. I live on the unceded and unsurrendered territories of the Mi'kmaw people where the Peace and Friendship Treaties are in effect. I have just finished my first year as a full-time teacher. Although I was nervous about the many challenges I would face as a first-year teacher, my greatest anxiety manifested in an image I held in my mind of a classroom in mid-January, dark and gloomy because no sun could get through the thick winter clouds or the banks of snow piled against the classroom windows. The air in the classroom is stale, and my mood and the moods of the students are as dark as the clouds in the sky. I associated entering the classroom with disconnecting from the land on which I live, the land on which I grew up, the land I have returned to with greater urgency every time I have tried to venture away from it to pursue perceived opportunities. My personal relationship with Land provides comfort and stability, but it is not without tension. I recognize that there are many stories of this Land that were lost to the violent disruption of colonization, and that there are also stories that survived colonization which are not - and should not be-available to myself and other settlers. Making space for these stories to exist and to be retold, it seems to me, is the work that I and my students, mostly settlers themselves, must take up.

I vowed at the beginning of this school year to get myself and my students outside as much as I possibly could. Our administrators encourage it, as long as our time outside is tied to curriculum. But the brief classes I have been able to steal outside for have not given my students the opportunity to build a relationship with Land. As I began to recognize that a true relationship with Land could not be built through the thick brick and concrete of our gleaming new school, I started to understand that we had to get ourselves outside of them. 
My students could not begin to understand their places within the Social Studies and French language curricula I was supposed to be teaching them without understanding the colonization that allowed these histories to exist. As Styres (2019) wrote,

For those who want to live in deeply sacred and intimate relationship to the Land must understand that it first and foremost requires a respectful and consistent acknowledgement of whose traditional lands we are on, a commitment to journey a seeking out and coming to an understanding of the stories and knowledges embedded in those lands, a conscious choosing to live in intimate, sacred, and a storied relationships with those lands and not the least of which is an acknowledgement of the ways one is implicated in the networks and relations of power that comprise the tangled colonial history of the lands one is upon. (p. 29)

My students were not in touch with any aspects of this inside the school, but they might begin to understand it if we could build a relationship with Land.

\section{Katelyn}

My name is Katelyn Copage, and I am an L'nu woman from Sipekne'katik, a Mi'kmaw community on the mainland of Nova Scotia. I am the first-born daughter of Jennifer and Kevin Copage, and the eldest sister to six siblings. I grew up on a dirt road where almost every house was filled with members of my family. I grew up climbing the same apple trees my Dad grew up climbing, in a place where my body was always able to communicate intimately and effortlessly with my homelands.

When I moved away for university, my entire world changed. Halifax seemed too fast paced to embrace my shocked body. I lived in a tiny apartment on a busy street with people I didn't know. I felt so removed from my home. I began to struggle with bulimia-not because I wanted to change my body shape, but because the food I could afford in the city felt toxic inside my body. I was completely disconnected from my Land, my body. I had internalized the compartmentalization logic settler colonialism needs to exist. I allowed myself to think that this, anything, could separate me from my home(lands).

My body is probably not like the Indigenous bodies your mind conjures when you think of us - genetic gifts from both of my parents have left me looking like a settler: light skin, blue hair; a half-breed. My bodily experiences differ from Indigenous persons with brown skin. My bodily experience is infused with the duality of Indigenous and Western ideologies - what Mi'kmaw Elders Murdena and Albert Marshall refer to as Etuaptmumk: two-eyed seeing (Bartlett, Marshall \& Marshall, 2012). Etuaptmumk teaches us that there are (at least) two equally valid ways of knowing the world - the Western and the Indigenous. Too often, we only see things through one eye - the Western. Etuaptmumk asks us to open both eyes and see the world with more complexity and beauty. It is a validation of the multiplicities within me and a profound counter to compartmentalization logic, which is a necessary facet of settler colonialism. The separation of Indigenous peoples from their bodies is a necessity in achieving the goal of settler society: the eradication/assimilation of Indigenous peoples from their homelands which removes powerful barriers standing in the ways of capitalist extraction of natural resources on indigenous lands $(\mathrm{Q}$. Christie-Peters in IDA Stanford, 2019; Simpson, 2014; Wilson \& Laing, 2019). 
I haven't always shown my body the love it deserves. There are so many emotions running beneath the surface of my flesh - my stardust atoms reaching beyond my skin to feel the totality of interconnectedness the rest of Western society seems to disregard. When I was younger, I didn't understand how to be a half-breed; I didn't understand what it was to live as a contradiction to Western society-and to be happy.

I didn't understand that an L'nu woman could love her body separately from the physical appreciation of a patriarchal society. I didn't understand that it wasn't relief I was experiencing when I cut open my flesh, observing my blood pool and spill over my hip, like the floods in spring. It was a manifestation of settler colonialism, the separation and disassociation of myself from my body because settler colonialism cannot exist whilst Indigenous peoples remain connected to their bodies, to their homelands.

But I understand now that my homeland is within my body, and my body is of my homeland. I refuse to allow the compartmentalization of my self any longer. No longer will I view myself as pieces of contradictions trying to occupy the same physical space as this body. Anishnabeeg visual artist Quill Christie-Peters says:

Our homelands are not that simple and static. Our homelands are not just those physical places we come from. Our homelands are our bodies and our ancestors, story and song embedded in river and rock, story and song embedded in our bones and blood. (IDA Stanford, 2019)

\section{Adrian}

In rough voice Ji'nm trembles:

"Jipasi eta migwite'lmul."

Wskitqumu replies,

soft like grass underfoot:

"You were part of me

once.

Mussal;

a piece

of something larger,

gadu

fear drove you away.

Wenmajita'si

aqq

meskeyi." 
Silence lingers;

can't remember (my way) home.

\section{Strand Two: Reading Rivers}

For each of us, the notion of Land with a capital L, which "refers not only to place as a physical geographic space but also to the underlying conceptual principles, philosophies, and ontologies of that space" (Styres, 2019, p. 27), is intimately represented and embodied through waterparticularly rivers. The rivers around us are a part of our daily lives and an intimate part of how we conceptualize our sense of place; they are also places with long histories of colonial violence against their caretakers, the Wolustoqey (Bear Nicholas, 2011) and the Mi'kmaq (Paul, 2006; see also George, 2019b), and against the rivers themselves (Perley \& Beaton, 2019; see also Lutes, 2019). In this strand of our braid, we share our stories of coming to read the rivers of DawnlandWabanaki territory.

\section{Rachael}

The morning is cold and damp, and the rain starts as soon as we arrive at French Fort Cove. As always, I am struck by the ways that colonization shapes the landmarks of my city. Although the Mi'kmaq have lived on this waterway for over 3,000 years, their settlements are outside of the current city centre, and the community has an out-of-sight, out-of-mind philosophy with regard to Metepenagiag, Natoaganeg, and Esgenoopetitj First Nations. Relationships are being built and strengthened between the city and the leadership in these three communities, but the move towards visibility feels slow. I have brought my students to the remains of a fort built by the French to protect their new settlement from the attacking British. Today, they have the opportunity to spend the day hiking, playing, and canoeing, and the irony of my attempt at connecting them with the Land in a place that so thoroughly erases the existence of the people who have lived here the longest is palpable to me. I try to focus on the importance of spending a day outside despite the cold rain, living with the weather instead of around it, and on the respect my students will gain for the river as they learn to navigate it in canoes. I think about how Metepenagiag, Natoaganeg, and Esgenoopetitj are connected by waterways, how integral canoes were to the Mi'kmaw way of life, how birch bark and spruce sap provided means of communication, travel, and prosperity to these communities and countless others across the land. I think of how we are giving the students the opportunity to learn independence and self-worth and the importance of relationship with Land that can be built on over time. I shiver as I realize that I haven't dressed properly for the wet weather and know that I still have a lot of respect to learn as well.

\section{Pam}

My partner and I own a house along the Wolastoq, about 23 kilometers downriver from Fredericton. It is a very old settler home-historically designated-which as I write this strikes me as ironic given that indigenous inhabitation preceded this house by over 13,000 years. Wolastoqik scholar Andrea Bear Nicholas (2011), in her chapter Settler Imperialism and the Dispossession of the Maliseet-Wolastoqiyik, 1758-1765, describes, through a precise detailing of cartographic erasure, how deliberate settler sleight of hand with map making and place naming resulted in the theft of 1.5 million acres of land from the Wolustoqiyik in 1760. It is a meticulously detailed account of outright theft and manipulation. Our house sits on one acre of these 1.5 million 
acres. It is one of the first settler houses remaining; we are stewarding colonial rather than the Indigenous histories, and through the floodings over the past two years, the Wolastoq River, the beautiful and bountiful river, has been making herself heard - to us, loudly.

This beautiful and bountiful Wolastoq River, as you may know, left her bed this spring, and last, and flowed across much of Wolastoqik territory on either side of her banks. There were not the usual two spring freshets - there was one enormous flow of water. In 2018, the water came into the house higher than the flood mark of 1887 . We were surprised and not prepared. This year, we were better prepared for her entry into our home. We expected her. What I am struck by as we work in and around the house this year and last — taking up silt and other gifts left by the Wolastoq is the immensity of the river, its aliveness, its right and ability to flow over the land, its energy, and effects.

I am also struck by the mark making of the river on walls and furniture, and the retention of the river in swollen doors and drawer. Her constancy within the house evokes in me an everpresent, thought-feeling wonderment. Over time and space, the Wolastoq-taking up the settler colonial effects of deforestation, settler habitation, larger snowpacks, the more southerly flow of the polar vortex, climate change-will reclaim the land upon which the house sits: the unceded and unsurrendered.

As a settler and treaty person, water is one of my neighbours I can learn to relate to as one way to better understand my/ourselves, our relationships with Indigenous peoples, my/our worlds, and how the land is speaking to me/us. These literacies of the land are telling me/us vociferously that much needs changing. The Wolustoq's speaking reminds me of the words of Leanne Betasamosake Simpson (2017b), Michi Saagiig Nishnaabeg scholar, writer, and artist, as she writes about the big water, the Chi'Niibish (Lake Ontario), creeping over the Lakeshore, drinking up Union Station, smothering the beach, bathing the train tracks, and she then surmises about the water's actions; "She is full. She is full of sad. She wants us to see her, to see what we are doing to her, to change" (p. 68).

\section{Adrian}

Sipu (River)

erodes the beds

in which she lay;

militant activist

challenges daily through presence.

Voice soft

like warm breeze

under tired wings

She says:

ankami, 
ika'li,

aqq

l'mie;

be gone

so I may live.

\section{Katelyn}

I take my rubber boots off and walk along the cool, moist banks of the Nashwaak river-a tributary of the Wolustoq. I immediately see four boats with people fishing; it is the first nice day we have had in two weeks and of course everyone is out. But I yearn for the quiet waters of Nashwaak to lull me in her ripples.

It's fiddleheading season in Wabanaki, but it's not safe to harvest the fiddleheads near my house. For the past two years, we have experienced a rise in spring river waters of which houses were not built in consideration. Gasoline and furnace oils run into the flood waters, compromised septic systems, leaching raw sewage into its being, contaminating the growth along the riverbeds and all those that depend upon these waterways to sustain life. Blue green algal blooms feed on the extra nitrogen and phosphorus (from ag. fertilizers and septic systems) leaching into the flood waters (Government of New Brunswick, n.d.). Three dogs died last summer after swimming in the river. Climate change is not just physical; the spiritual, behavioral, and emotional climate has changed/is changing as well.

I think about the humans who would have fished this river thousands of years ago, when it was plentiful with salmon and its waters were not poisoned. The first written record of declining fish in this river was in 1776, when English settlers built a dam and the Wolustoqiyik threatened to destroy it in order to protect the fish by asserting their Treaty rights (Hall, 2015). Then there was the Stanley Lumber Mill built further up river, and the Marysville Mill, which processed cotton shipped up the waterways from Georgia. This body (of water) has experienced trauma.

Yet despite this environmental trauma, I feel at home- the pervasive chattering of my anxieties no longer persisting. My lungs can fill more completely with air when my bare feet are steady upon the Earth, they reach down through my feet and root themselves.

\section{Adrian}

In his recent novel, Taapoategl and Pallet, Mi'kmaw novelist and artist Peter J. Clair (2017) considers the rain through the perspective of his title character, Taapoategl: "She likes the rain falling on her face... She doesn't understand why people always cover up when it rains. As the rain falls, it awakens a special awareness and stirs her shaken life" (p. 67). After reading this line, I considered all the memorable rainfalls that have stirred my life-displaced, disjointed, and sometimes disconnected from my (home)Land though they may have been, these rains always remind my body of home and awaken ancestral connections, deep with(in) my being.

There was a moment one morning while I was teaching in Eeyou Istchee (Northern Quebec), where I stayed in bed for an extra 10 minutes, just to listen to the symphony the rain was producing as it fell upon my rooftop. In that moment, I knew I had changed. A younger version of 
me would have called into work sick and stayed there all day. There was a moment a few years earlier while teaching in Ilula, Tanzania when I felt the rain on my face and thought that the only thing I was sure about in my life was that I never wanted to stop loving the rain. I reflect on that moment often, and it still holds true. There was a moment while I was teaching just outside of Mae Tan, Thailand when I saw a rainstorm approaching, starting over a forest in the distance, and moving toward us, lingering over the rice fields next to our classroom. As it drew near, I saw a distinct line of rain in the sky and on the ground. On one side of the line, the ground was wet; on the other side, it was dry.

The movement of rain on that warm November day in 2010 has stayed with me in vivid detail, and it continues to stir me - to move my think/feeling in unexpected directions and to awaken buried understandings. Reflecting on the image now, I think of binaries and the liminal spaces between them. Settler colonialism intrudes on the land through oil spills and industrial run off. Rivers intrude on our settler colonialisms through floods that wash away all we considered permanent. There is an ebb and flow, a give and a take, a negotiation between Land and settler colonialism - nothing is indifferent to anything else. The relationship exists, but the ability, willingness, and capacity to see it is not guaranteed.

What stirs us to see the unseen? Perhaps the unstoppable torrent of a river flooding into our home calls us to action. Perhaps rivers of oil polluting the places we hold dear remind us of the "permanence" of settler colonial occupation. Perhaps a line in a novel lingers at the periphery of our consciousness for days, weeks, years. For me, like Taapoategl, it is the rain that brings about awareness and reminds me that there are things in this world which cannot be tamedunderstandings which have been erased, disappeared, and buried but which cannot be hidden away forever. The rain feeds the river and both erode the permanence of our erasure. The rain is present. The river is resurgent. The ocean cannot be ignored. Water stirs me to see the unseen; water moves me to read place.

\section{Strand Three: Future Making}

In recent years, there has been a tangible movement in indigenous studies toward discussions of the future. In a widely read and cited article from 2013, Eve Tuck and Rubén GaztambideFernández discuss the future envisioned within the settler colonial project as being one of indigenous erasure; in order for settler colonialism to thrive, Indigenous peoples must disappear. Many other authors have also written about the settler colonial desire for Indigenous peoples to disappear from the land (e.g., George, 2019b; Mitchell, 2018; Simpson, 2017a), and indeed Canadian politicians of the 1970s and earlier are well-known for their desire to be rid of the "Indian problem" (See Palmater, 2011).

Tuck and Gaztambide-Fernández (2013) respond to the erasing project of settler colonialism with a revisioning of indigenous futures - an unapologetic assertion of indigenous presence in the moment in order to secure an indigenous future. Many other Indigenous writer/thinker/scholars also have taken up the project of envisioning futures beyond settler colonialism (e.g., Goodyear-Ka‘ōpua, 2019; Simpson, 2017a). Indeed, in this moment, for us it is not enough simply to see settler colonialism at work on Land, nor is it enough to help others see its workings. Action is an ethical imperative. We must find ways of challenging and disrupting settler colonial understandings of place; we must find ways of subverting the normativity of those understandings; we must find ways of asserting indigenous presence in the moment in order to 
ensure indigenous futures. In this final strand, we take up the ethical imperatives of reading place. We work towards active meanings of what it means to live well in our place(s) and how to encourage others to do the same.

\section{Adrian}

In a 1994 edited collection entitled Kelusultiek: Original Women's Voices of Atlantic Canada, Mi'kmaw artist and poet Mary Louise Martin offers powerful insight into what it means to be an Indigenous artist. Martin (1994) begins her poem, "Profile," with an acknowledgement that being an artist does not mean one is creator. The poem then connects creative process to the natural creative state of the world around us. As Indigenous artists, we are inhabited by creation; the spirit moves through us as we give birth to a poem/song/dance/painting/novel (Maracle, 2014). Martin ends the poem first by confidently asserting that she is a native artist and then by humbly thanking creator and her relations.

Martin's words reverberate deep within me. They touch a sleeping knowledge, an embodied literacy of cosmic creativity carried forward in the brilliant blood that flows in my veins - and through Katelyn's. I am moved by creation; I am interested in breathing life into the world around me, drawing on the sacred wind within and using it to carry my words forward, altering the physical reality of the space/place upon which we live (see also Cajete, 2000). I heartlisten to the words of Vicki Kelly (2019), who recently wrote that "Indigenous knowledge practices are ecological encounters of profound ethical relationality that acknowledge the act of co-creating through living embodiments of Indigenous Poiesis" (p. 17). These poems do not belong to me; the words of the Mi'kmaw language, which have been shared with me by knowledgeable Elders and language keepers, write their own poems. I am here only to observe and learn from the language. There is a deep conversation happening in my heart of which I can only hear the whispers-like a child with their ear pressed against the bedroom door. The muffled sounds of 13,000 years of ecological encounters and co-creation, learning from, with, and through Land (Simpson, 2014).

The future is in creation, not to be confused with innovation, creativity, or creative problem solving. These latter terms have the ring of neoliberal globalization and the exploitative capitalist mindsets that have undermined the sovereignty of Indigenous nations the world over and made a commodity of our sacred lands/bodies (Coulthard, 2014; George, 2019b; Goodyear-Ka'ōpua, 2019; Simpson, 2017a). Creation, on the other hand, is happening around us all the time-a cyclical, relational growth. When we open ourselves up to the knowledges embedded in creation, we become aware of the sacredness of our ecology (See Cajete, 1994) -we live with attentive awareness to the sacredness of life within ourselves, each other, the natural world, and the cosmos (See Stonechild, 2016). We live in indigenous poiesis; we live in creation.

Migwite'lmul / I remember you

Mu' nugu' pugweltnug nipugt esgqiaq ula gm'tginug ${ }^{4}$

gadu migwite'lmul.

Wskitqumu 
never left,

but is harder to hear now.

L'nu teluet ula guntew mimajig, ${ }^{5}$

and she does,

but it is easy to forget.

So ask:

Kisi wantaqpitis?

Keska'n?

Kisi Apoqnmultis?

Can we

be whole again?

Niskam,

Alasutmay.

I am praying.

For you.

For me.

For hope.

\section{Rachael}

Over the course of this past year, my two teaching partners and I worked on large-scale projects with our 57 Grade 6 students. In September, the students created their own political parties that reflected their interests in equality, fairness, and the environment, which drew the ear of our city's mayor and the provincial legislature. In December, they all became successful entrepreneurs who created, tested, and manufactured their own products, drawing our community into the school for a sell-out market. Over the winter months, they innovated in our inventors' workshop, using the scientific method to invent a solution to a real-world problem. And finally, in the fourth of our four projects, these students were given the chance to become caretakers of a storied piece of land within our community.

This piece of land provided a summer hunting camp for the Mi'kmaq for thousands of years. It was a refuge for Acadian people driven from their homes during the Deportation. Scottish and Irish shipbuilders used its shores for their work (https://www.beaubearsisland.com). Today, it is a national park donated by its last private owner to the government of Canada. As I started to dream about this project in the depths of winter, I imagined an entire month spent living and learning on the land. I pictured that we would go outside every day, canoe and boat across the river 
to Beaubears Island, known in Mi'kmaw as Quoomeneook, or island of pine trees. We would spend hours each day taking care of the land and its restored trail system, learn from Mi'kmaw Elders about the medicines and histories of the First peoples of the land, and learn from local historians and ecologists about their perspectives on the island. I thought that I was dreaming too big, but thanks to supportive administrators, my trusting teammates, and a lot of determination, it turned out that my students got to spend eight days outside in the last two months of school. Our plan was to spend four consecutive Thursdays on Quoomenegook, which was reduced to two, but involved last-minute changes that tested our students' resilience and provided rich learning experiences. They passed swim tests, spent three days learning to canoe under expert instruction, and researched the history of the area and the people who have lived here. They built a relationship with Donna Augustine, a Mi'kmaw Elder from Elsipogtog First Nation; met ecologists; learned from historians; and produced beautiful products - projects of their own choosing that represented their learning. They created art pieces from found natural materials, models of the outdoor spaces where they learned and played, and photo books and artwork that represented the land they inhabited over the course of the project. During the eight days they spent outside, it was my greatest hope that through building a relationship with a piece of land and its varied stories, these students would begin to understand their roles as settlers, as treaty people, and the ways that the land(s) we live on and with shape and are shaped by these roles and responsibilities.

\section{Adrian}

A closing thought left to linger: Toward the end of his novel Taapoategl and Pallet, Clair (2017) has his character Pallet comment on the future: "He doesn't want to know the future; he wants it to be a pleasant surprise. If he knew the future, he may spend too much time preparing. What he wants is just to lead a good life and keep to a small footprint" (p. 171).

\section{Tying off}

The idea of reading place can mean many things, and we do not want to limit your understanding by enforcing ours. There are, however, a few threads worth pulling on.

For us, reading place is about understanding the ways in which settler colonial understandings of place were, and continue to be, mapped on top of pre-existing indigenous understandings of those same places. This is particularly clear for us in the work of Bryant (2017) and Indigenous scholars such as Styres (2019) and Battiste (1984, 2016b), who point to the ways in which the "storied landscape of land" (Styres, 2019, p. 29) was erased, displaced, and replaced with a different narrative. Further, as Katelyn has suggested, the Land and our bodies are one and the same, and the cartographic dissonance that comes from having one map enforced on top of another also forces us to redraw the maps of our bodies and the ways we care for them.

For us, reading place is a necessarily future-oriented project. It is our hope that by understanding the manifestations of settler colonialism on the Land with which we live, and by helping others to see the storied landscapes of land as an act of praxis in all our lived contexts, we can all learn what it means to live well in our places. Each of us have our own questions and insights, and we encourage you to consider and (re)construct your own.

\section{Adrian}

Petroglyphs are part of the Mi'kmaw writing system that Marie Battiste (1984), in her doctoral dissertation, articulated as a precontact form of literacy. In my understanding, it was a 
different kind of literacy than we might be used to - the symbols were not read phonetically, but rather they were spoken through holistically. In some ways the poems I write are an attempt to reclaim that literacy - to speak through the different symbols of our natural world and perhaps to contribute something to the "storied landscape of Land" (Styres, 2019, p. 29). How might you, dear reader, speak through our writing here?

\section{Pam}

When I read Adrian's poems, it feels as though the two languages he places beside, above, or below each other open up Land, enact cartographic dissonance, help me/us to see and hear and listen to and for the multiplicities of the storied Land where we live.

\section{Rachael}

Reading Katelyn's deep personal and familial history with her homeland, I am made hopeful that my students will remember the days we spent working and playing outside together in the years to come. I wonder whether they, like me, like Katelyn, will have their relationship with this Land come into sharper focus if and when they must travel elsewhere. I wonder how the resurgence of the Mi'kmaw communities of my region will shape and impact the stories we know and remember going forward, and how we will all grow and struggle together through the tensions that come from voices raised against a long-defended story of colonialism. I wonder about the ways that I can use my place as an educator and as a settler to make more space for these stories to emerge.

\section{All}

To close with our appreciation of métissage, we turn to Robin Wall Kimmerer (2013) who reminds us that sweetgrass braids "are given away as signs of kindness and gratitude" (p. 203). We are not interested in being perspective or didactic in our writing/sharing/thinking/teaching. Rather than refining/defining our meaning(s), we offer you this braid - our métissage - as it is, as a gesture of kindness and gratitude. Our kindness extends to all our relations, but the gratitude of this moment is yours alone-we thank you for reading our words and for building a relationship between us. We ask that you carry them forward and pass them along with kindness and gratitude.

\footnotetext{
Endnotes:

${ }^{1}$ Throughout this article, we use Land with a capital "L" to refer both physical place and the onto-epistemic understandings embodied in place. The word land with a lowercase 1 is used to refer solely to physical place. This usage is modeled after that of Sandra Styres (2019).

2 Capitalization conventions are those of the journal.

3 The term Wabanaki translates as "people of the dawn" in most Wabanaki languages (e.g., Mitchell, 2018). According to Elder Dr. David Perley, the Wabanaki nations are called as such because they are the first to greet the sun in the morning, being the most easterly nations of Turtle Island (D. Perley, personal communications, October 17, 2019).

4 "There isn't much forest left here in our territory" translation retrieved from https://www.mikmaqonline.org/servlet/dictionaryFrameSet.html? $\arg 0=$ forest\&method=searchFromEnglish

5 "The native says that this rock/stone lives" translation retrieved from https://www. mikmaqonline.org/servlet/dictionaryFrameSet.html? arg0=alive\&method=searchFromEnglish
} 


\section{References}

Bartlett, C., Marshall, M., \& Marshall, A. (2012). Two-eyed seeing and other lessons learned within a co-learning journey of bringing together Indigenous and mainstream knowledges and ways of knowing. Journal of Environmental Studies and Sciences, 2(4), $331-340$.

Battiste, M. (1984). An historical investigation of the social and cultural consequences of micmac literacy (Doctoral dissertation, Stanford University). (UMI No. DA8408385)

Battiste, M. (2013). Decolonizing education: Nourishing the learning spirit. Saskatoon, SK: Purich.

Battiste, M. (Ed.). (2016a). Living treaties: Narrating Mi'kmaw treaty relations. Sydney, NS: Cape Breton University Press.

Battiste, M. (2016b). Mi'kmaw symbolic literacy. In M. Battiste (Ed.), Visioning a Mi'kmaw humanities: Indigenizing the academy (pp. 123-148). Sydney, NS: Cape Breton University Press.

Bear Nicholas, A. (2011). Settler imperialism and the dispossession of the Maliseet, 1758-1765. In J. G. Reid \& D. J. Savoie (Eds.), Shaping an agenda for Atlantic Canada (pp. 21-60). Halifax, NS: Fernwood.

Brayboy, B. M. J. (2005). Toward a tribal critical race theory in education. Urban Review: Issues and Ideas in Public Education, 37(5), 425-446. doi:0.1007/s11256-005-0018-y

Bryant, R. (2017). The homing place: Indigenous and settler literary legacies of the Atlantic. Waterloo, ON: Wilfrid Laurier University Press.

Cajete, G. (1994). Look to the mountain: An ecology of indigenous education. Durango, CO: Kivakí Press.

Cajete, G. (2000). Native science: Natural laws of interdependence. Santa Fe, NM: Clear Light.

Chambers, C., \& Hasebe-Ludt, E., with Donald, D., Hurren, W., Leggo, C., \& Oberg, A. (2008). Métissage. In J. G. Knowles \& A. L. Cole (Eds.), Handbook of the arts in qualitative research: Perspectives, methodologies, examples, and issues (pp. 141-153). Thousand Oaks, CA: Sage.

Clair, P. (2017). Taapoategl \& pallet: A mi'kmaq journey of loss \& survival. Woodstock, NB: Chapel Street.

Coulthard, G. S. (2014). Red skin, white masks: Rejecting the colonial politics of recognition. Minneapolis, MN: University of Minnesota Press.

DeMont, J. (1992). Citizens Irving: K. C. Irving and his legacy. Toronto, ON: McClelland \& Stewart.

Donald, D. (2012). Indigenous métissage: A decolonizing research sensibility. International Journal of Qualitative Studies in Education, 25(5), 533-555. doi:10.1080/09518398.2011.554449 
George, C. T. (2019a). Decolonize, then indigenize: Critical insights on decolonizing education and Indigenous resurgence in Canada. Antistasis, 9(1), 73-95.

George, C. T. (2019b). Exploring Wabanaki concepts of holism and Longhouse knowledges. Antistasis, 9(2), 1-14.

Glynn, T. (2017, May). Return of the Wolastoq: Giving a river back its name. NB Media Co-Op. Retrieved from http://nbmediacoop.org/2017/05/26/return-of-the-wolastoq-giving-ariver-back-its-name/

Goodyear-Ka'ōpua, N. (2019). Indigenous oceanic futures: Challenging settler colonialisms \& militarization. In L. T. Smith, E. Tuck, \& K. W. Yang (Eds.), Indigenous and decolonizing studies in education: Mapping the long view (pp. 82-102). New York, NY: Routledge.

Government of New Brunswick. (n.d.). Blue-green algae. Retrieved from https://www2.gnb.ca/content/gnb/en/departments/ocmoh/healthy environments/content/b lue green algae.html

Hall, J. (2015). River of the three peoples: An environmental and cultural history of the Walastaw /rivière St Jean/St. John River c1550-1850 (Unpublished doctoral dissertation). University of New Brunswick, Fredericton, New Brunswick.

Hart, M. A. (2002). Seeking mino-pimatisiwin: An Aboriginal approach to helping. Halifax, NS: Fernwood.

Hasebe-Ludt, E. (2010). A love song to our pluriverse: Life writing as cosmopolitan motherwise text. Transnational Curriculum Inquiry, 7(2), 39-46. Retrieved from https://ojs.library.ubc.ca/index.php/tci/article/view/2036

Hasebe-Ludt, E., \& Jordan, N. (2010). "May we get us a heart of wisdom": Life writing across knowledge traditions. Transnational Curriculum Inquiry, 7(2), 1-4. Retrieved from https://ojs.library.ubc.ca/index.php/tci/article/view/2035

IDA Stanford. (2019, April 10). Long live our mother week 2: Indigeneity, Land history, and environmental justice [Video file]. Retrieved from https://www.youtube.com/watch?v=b3RkvPJjuJw

Justice, D. (2018). Why indigenous literatures matters. Waterloo, ON: Wilfrid Laurier University Press.

Kelly, V. (2019). Indigenous poiesis: Medicine for Mother Earth. Artizein: Arts and Teaching Journal, 4(1), 17-30. Retrieved from http://opensiuc.lib.siu.edu/atj/vol4/iss1/

Kress, M., Perley, I., Perley, D., Plaice, E., \& Sabattis-Atwin, A. (2019). “Ktuhkelokepon” Awakening our indigeneity: A Wabanaki story of truth, justice and reconciliation. Antistasis, 9(1), 1-12.

Kimmerer, R. W. (2013). Braiding sweetgrass: Indigenous wisdom, scientific knowledge and the teachings of plants. Minneapolis, MN: Milkweed . 
Kuby, C., Spector, K., \& Johnson Thiel, J. (Eds.). (2019). Posthumanism and literacy education: Knowing/becoming/doing literacies. New York, NY: Routledge.

Lutes, A. (2019, September 10). Water in New Brunswick: Rights and the environment versus big business. NB Media Co-Op. Retrieved from http://nbmediacoop.org/2019/09/10/water-in-new-brunswick-rights-and-theenvironment-versus-big-business/

Maracle, L. (2014). Indigenous poetry and the oral. In N. McLeod (Ed.), Indigenous poetics in Canada (pp. 305-310). Waterloo, ON: Wilfrid Laurier University Press.

Martin, M. L. (1994). Profile. In R. Usmiani (Ed.) Kelusultiek: Original women's voices of Atlantic Canada (p. 163). Halifax, NS: Institute for the Study of Women, Mount Saint Vincent University.

Mitchell, S. (2018). Sacred instructions: Indigenous wisdom for living spirit-based change. Berkley, CA: North Atlantic Books.

O'Donnell, B. (n.d.). Indian and non-Native use of the Miramichi River: An historical perspective. Native Affairs Division Issue 10: Fisheries and Oceans: Canada

Orr, D. (1994). Earth in mind: On education, environment, and the human prospect. Washington, DC: Island Press.

Palmater, P. (2011). Beyond blood: Rethinking Indigenous identity. Saskatoon, SK: Purich.

Paul, D. (2006). We were not the savages: Collision between European and Native American civilizations (3rd edition). Halifax, NS: Fernwood.

Paul, D. (2017). Chief Lightning Bolt. Halifax, NS: Roseway.

Perley, D. (n.d). Overview of Maliseet and Mi'kmaq history. Unpublished paper, University of New Brunswick, Fredericton, Canada.

Perley, D., \& Beaton, B. (2019, March 20). Wolastoq: A beautiful and bountiful teacher. NB Media Co-op. Retrieved from http://nbmediacoop.org/2019/03/20/wolastoq-newbrunswick-and-canadas-teaching-waterway/

Pictou, S. (2017). Decolonizing Mi'kmaw memory of treaty, L'stttkuk's learning with allies in struggle for food and lifeways [Doctoral dissertation]. Dalhousie University, Halifax, Nova Scotia, Canada. Retrieved from https://dalspace.library.dal.ca/handle/10222/72811

Simpson, L. (2014). Land as pedagogy: Nishnaabeg intelligence and rebellious transformation. Decolonization: Indigeneity, Education \& Society, 3(3), 1-25.

Simpson, L. (2017a). As we have always done: Indigenous freedom through radical resistance. Minneapolis, MN: University of Minnesota Press.

Simpson, L. (2017b). Big water. In This accident of being lost: songs and stories (pp. 65-68). Toronto, ON: House of Anansi Press.

Stonechild, B. (2016). The knowledge seeker: Embracing indigenous spirituality. Regina, SK: University of Regina Press. 
Styres, S. (2019). Literacies of land: Decolonizing narratives, storying, and literature. In L. T. Smith, E. Tuck, \& K. W. Yang (Eds.), Indigenous and decolonizing studies in education: Mapping the long view (pp. 24-37). New York, NY: Routledge.

Tuck, E., \& Gaztambide-Fernández, R. A. (2013). Curriculum, replacement, and settler futurity. Journal of Curriculum Theorizing, 29(1), 72-89. Retrieved from http://journal.jctonline.org/index.php/jct/article/viewFile/411/pdf

Tuck, E., \& McKenzie, M. (2015). Place in research: Theory, methodology, and methods. New York, NY: Routledge.

Vermette, K. (2018). River woman. Toronto, ON: House of Anansi Press.

Wilson, A., \& Laing, M. (2019). Queering indigenous education. In L. T. Smith, E. Tuck, \& K. W. Yang (Eds.), Indigenous and decolonizing studies in education: Mapping the long view (pp. 131-145). New York, NY: Routledge.

Zaidi, R., \& Rowsell, J. (Eds.). (2017). Literacy lives in transcultural times. Abindgon, UK: Routledge. 